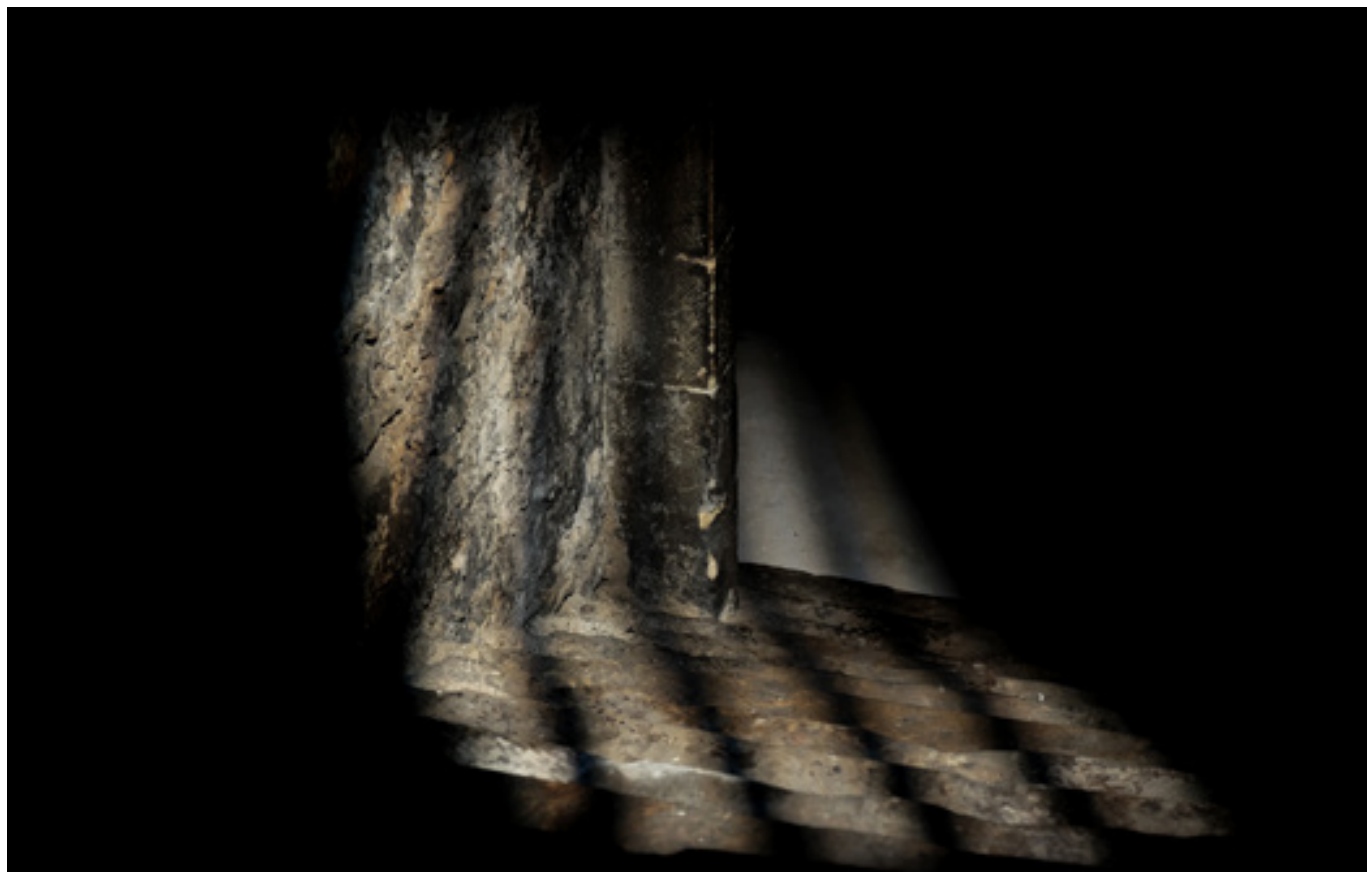

\section{Harsh Justice?}

Tobias SMITH

What makes a penal system 'harsh'? Can penal severity be compared across time and place? In the case of China, the question of how to evaluate relative severity in punishment is not just methodological; it is also political. This essay discusses why this type of comparison is sensitive, and why nonetheless it is not possible to avoid talking about it. The article suggests a variety of approaches for assessing penal severity in China, and cautions against relying on any one of them.
Prison PC: Guido Oliveti (flickr.com).

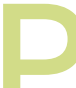

unishment is by nature a harsh business. But it is not uniformly harsh. There is wide variation in punishment across time and place, a fact that makes periods like the Inquisition so evocative. But although we can readily identify particular punitive moments that are notably severe or lenient, can we more generally compare penal severity from one place or time to the next?

In the book Harsh Justice: Criminal Punishment and the Widening Gap between America and Europe (2003), law scholar James Q. Whitman examines the relative severity of punishment in the United States and Continental Europe. Whitman takes it as a starting point that the contemporary US system is harsher than its counterpart-he points to American mass incarceration, the death penalty, long sentences for juveniles, and a litany of other evidence. But Whitman also recognises 
that harshness is not a single, straightforward metric. He goes on to list no fewer than ten possible ways to define 'harsh' punishment, including harshness in criminalising conduct, harshness in the application of punishment, and harshness as lack of respectful treatment in prisons. A system can be harsh because it detains lots of people, or harsh because it doles out very long sentences for a relative few. It can also be harsh because it refuses to countenance acts of mercy. Harshness, then, is an openended and contentious term.

As an American researcher who studies criminal justice in China, I read Whitman's work with a mix of admiration and unease. Comparison is always tricky business. At least in the transatlantic comparison, the researcher may rely on a shared cultural history and a reservoir of implicit good faith in the comparative undertaking. Indeed, Whitman's work is premised on a store of widely accepted assumptions about social status in the West. $\mathrm{He}$ argues that punishment in the United States is harsher than in Europe because in the American democratic tradition criminals are stripped of all status and universally placed at the bottom of the social hierarchy; the lowest common denominator is degrading penal treatment. Meanwhile, in the European tradition, the social privileges once afforded only to aristocrats gradually expanded to include common criminals, so the relative lenience and dignity reserved for European nobility is now enjoyed by all citizens in the criminal justice system. I may disagree with Whitman's conclusions, but I do not doubt the sincerity of his enterprise, nor do I worry that his depiction of harshness in the US carceral system is a smear. By contrast, I cannot help but think that a similar treatment of comparative harshness in the United States and China written today would be viewed by all sides as a provocation. Why is this?

From the get-go, Western comparative writing on punishment in China has toggled crudely back and forth between self-interested idealisation and crass demonisation. The Philosophes lionised the enlightened Chinese 'cult of justice' (Ruskola 2013, 46, 251); Hegel wrote of China's 'Oriental Despotism', and a host of European commentators decried late imperial punishment as exceptionally cruel and barbarous (Ruskola 2002, 214; Conner 2002). These exaggerations say more about debates taking place in the West than about anything happening in China. In the late twentieth century this navel-gazing comparison travelled both ways, as the Chinese Communist Party began using American criminal justice as a convenient political foil. Today the United States and China issue annual reports castigating one another's penal policies; reading these reports side-by-side is like watching two sports teams play different games badly on the same field-with both insisting that they are winning.

Given these historical and contemporary circumstances, it is not surprising that much of the research on punishment in China is aimed not so much at comparison, but at a better understanding of China on its own terms (e.g. Kiely 2014; Trevaskes 2012; Brook et al. 2008). This is true not only for punishment, but also for recent scholarship on related concepts of justice, and rule of law and human rights (e.g. Sapio et al. 2017; Fu 2019b), all of which overlap with penal severity, even if none quite capture it. The difficulty is that while it is possible to undertake research on punishment in China without comparison, it is much harder to undertake conversation about this topic without comparison. Over and over again-at conferences and in office hours and at dinner parties in both China and the United States-I find that talk about Chinese penal practice turns comparative. And it usually goes something like this:

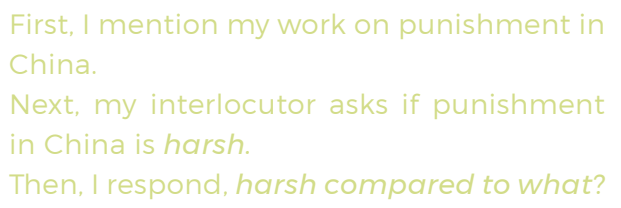


And suddenly we are comparing. When asked: compared to what?, most people choose either place or time. If place, people ask: which criminal justice system is harsher-the United States or China? Or, if time, the question goes something like this: is punishment in China becoming milder than in the past? These queries are pursued, so far as I can tell, with sincerity and curiosity. And as a scholar I feel obliged to give-if not an answer-at least a framework for thinking through the inquiry.

Here I endeavour to provide a few entrypoints for seriously engaging in a conversation about just how harsh penal practice is in China. There is no single golden measure of comparative severity in punishment, but the frames below all offer possible approaches to consider. The following sections more or less follow the responses I provide-usually in the Socratic mode-when I get these queries myself.

\section{Incarceration Rates and Penal Severity}

Because we so often look to statistics for comparison, numbers are an obvious starting point for a discussion of penal severity. Whitman starts his analysis in this way, pointing to the scale of American imprisonment. The United States has over two million prisoners and the highest per capita incarceration rate in the world, a rate more than tenfold that of some parts of Western Europe (Whitman 2003, 3). In terms of absolute numbers, China has the second largest prison population in the world, with about 1.6 million people held in Ministry of Justice facilities, according to the World Prison Brief (Walmsley 2018). Of course this comparison is skewed because of China's size. Adjusted for the denominator of population, these numbers put China near the global median (133 out of 222 countries) in terms of rate of incarceration, with a rate of 118 people per 100,000 . This is in the same ballpark as
France, Spain, Portugal, and other parts of Western Europe that Whitman had in mind in his comparative analysis.

Although rate of incarceration is initially an attractively simple yardstick for comparison of penal severity, things get complicated fast.

First, how does incarceration relate to other social phenomena? The United States, for example, has an extremely high rate of incarceration, but it also has an extremely high rate of violent crime for a developed nation, inviting the question of whether the scale of imprisonment may be fairly characterised as a harsh response given social conditions. The rate of violent crime in China, by contrast, is reportedly low. On one standard indicatorhomicide-China has among the lowest rates of crime in the world, according to the United Nations Office of Drugs and Crime. Punishment bears some relationship to crime, but criminologists remain divided about the nature of that relationship. If crime is an independent variable and punishment follows from crime in a mechanistic way, a high rate of imprisonment in a high-crime society may be viewed as entirely reasonable and not unduly severe. If, however, the relationship is viewed as more mutually constitutive-if, for example, incarceration produces the social inequality that drives crime-then a high crime rate may be further evidence of penal severity, rather than a justification for it.

Second, we might ask not just how many people are incarcerated, but for how long? The rate of incarceration is a snapshot of penal scale, rather than a dynamic indicator. Long prison sentences may be harsh, but lengthening sentences are not immediately evident in the incarceration rate. As an accounting matter, the impact of giving a prisoner a term of 20 years instead of 10 will not be visible in the prison rate for a decade. In the United States for example, the full impact of the turn to 'tough on crime' sentences in the second half of the twentieth century was not fully recognised for many years. Until recently custodial sentences in China-including sentences for serious 
crimes such as homicide-have not typically exceeded two decades (Smith and Jiang 2019, 75). However, as elsewhere in the world (Penal Reform International 2018, 11), sentences for serious crime are getting longer in China (Liang 2017,39-40). The eighth and ninth amendments to China's criminal law introduced a 25 -year minimum sentence for some recidivists and a life without parole sentence for bribe-taking (Smith and Jiang 2019). It is unclear how often these sentences are being used, and the impact of these sentences on overall incarceration is not yet visible.

Third, does the scale of incarceration capture the significance of relatively uncommon, but severe, penalties? For example, China is widely reported to be the world's leading executioner state, putting to death thousands of people a year (Amnesty International 2018). Capital punishment directly affects only a small portion of China's carceral population, but given the symbolic position of capital punishment as an extreme sanction that has been abolished in much of the world, it plays an outsized role in some assessments of severity. How much weight should we accord such a punishment in comparison?

\section{Transparency, Opacity, and Severity}

When we compare penal severity using criminal justice statistics, we assume some measure of validity. In the case of China though, this is a shaky proposition. Some data-such as death penalty statistics-are explicitly designated state secrets, so we must rely on estimates. Other data are aggregated in irregular ways. For these reasons, we may need to look beyond quantitative measures.

But data opacity is more than just a question of numbers: quantitative descriptors also reflect qualitative choices about punishment. When I give talks on the crisis of mass incarceration in the United States, I point out that that the modifier 'mass' points to more than just the total size of the prison population. Mass also denotes the mode by which the contemporary American penal system views prisoners as an undifferentiated group, an aggregate of stuff that has to be warehoused (Garland 2001). This orientation to criminal offenders-as a volume that must be processed-is a qualitative phenomenon that may be seen as severe irrespective of the scale of imprisonment in the United States. Colleagues in China have told me that swelling detainee populations are producing a 'mass' crisis in their country as well. State secrecy may conceal the scale of punishment; it may also conceal the mode of correctional response to scale.

While opacity might lead us to underestimate punishment in China, it is also possible that state secrecy leads us to overestimate the harshness of the Chinese penal apparatus. After all, the Chinese state can and does cultivate perceptions of punishment through the canny use of show trials and other propaganda. The state may be actively encouraging perceptions of penal severity to promote deterrence or boost perceptions of state stability. Indeed, the Chinese state is quick to brand its own penal policy with slogans that are starkly direct about state orientation to penal severity. The Maoist catchphrase 'Combining Punishment with Leniency' (惩办与宽大相结合), gave way to 'Strike Hard' (严打) and then 'Balancing Leniency with Severity’ (宽严相济) (Trevaskes 2017). On the one hand, these slogans serve as communicative tools that set real policy agendas on a continuum of punitivity; in this regard, we might take the state at its word that 'Balancing Leniency with Severity' moderated the penal harshness of 'Strike Hard'. On the other hand, because these slogans are first and foremost propaganda whose symbolic or performative meaning directs, rather than describes, material conditions, we should be careful not to equate severity of language with severity of punishment (Trevaskes 2017). 


\section{Rules and Exceptions}

When we think about comparators like incarceration rates, we orient towards aggregates and averages. But while harshness may be gauged by the typical penal experience, it may also be evaluated based on the atypical case-the exception, the outlier. In fact, one way to examine penal severity in China today is through the relationship between the norm and the anomaly. And whether one puts the emphasis on the norm and anomaly bears not only on whether one considers China's system harsh, but also on how one views the arc of that severity over time.

Legal scholars distinguish substantive law and procedural law. Substantive law spells out crimes and penalties; procedural law dictates how that law is enforced. The relationship between procedural protection and penal harshness is not fixed. A system may lack procedural protections and also be quite lenient (imagine a town where citizens have no due process rights, but the criminal code is brief, enforcement is lax, and sentences are short). Conversely, a regime could be procedurally rigorous and also severe. Whitman points out, for example, that the United States places great emphasis on procedural rights and also metes out extremely long sentences.

In the case of China, concerns about penal severity are often implicitly concerns about due process deficits. For example, wrongful conviction (Nessosi 2017) and death in custody (Dui Hua Foundation 2010) are both notorious issues in China. Even if incidents are rarewhich is uncertain-they are emblematic of local discretionary power producing variability in the harshness of punishment. By most accounts China has gone to great lengths to address this variation, most notably in recent amendments to the Criminal Procedure Law. Overall, these improvements mean that what we might imagine as the typical criminal justice defendant-the petty criminal at the local level-is less likely to experience arbitrary or personalised roughness at the hands of local authorities than during past eras of decentralised 'campaign style' justice. On this measure of typicality, China's penal system has arguably become less harsh in recent years.

Variation in penal harshness can also occur when some categories of offenses or offenders are marked for differential treatment. Although criminal procedure reforms may be improving treatment at the level of the individual, the imperative of state stability increasingly carves out zones of exception (Sapio 2010), creating a phenomenon of bifurcated or dual state punishment (Fu 2019a). Dual state punishment is most visible in areas of political crime. In some cases, the criminal law becomes stretched, as when dissidents are given extremely long sentences for nebulous crimes such as subversion. In other cases the law is flouted, as when political dissidents are simply disappeared (Wang 2018). And sometimes the law is officially overruled. At the upper echelons of political conflict, new regulatory organs have formal coercive authority. For example, the new National Supervisory Commission, an institution that officially enjoys co-equal status with the judiciary, has investigative and detention powers over Party members and state employees (Smith 2019; see also Caster's essay in the present issue). While these powers are set in statute, they also contradict the Criminal Procedure Law. The Commission signifies the current administration's willingness to establish unconstrained penality to address political dissent and corruption.

The biggest state of exception concerns the punishment of minorities, notably Muslim Uighurs, in the far West of China (see Byler's essay in the present issue). Ethnic and religious identity have emerged as twinned issues that the state seems to be carving out for harsh treatment with few if any checks on the severity of punishment. The 2015 Counterterrorism Law and related efforts to combat 'extremism' establish a vague basis for the administrative regulation and criminalisation of religious activities. For example, the Law regulates those who "wear or bear clothes or symbols that advocate terrorism in a public 


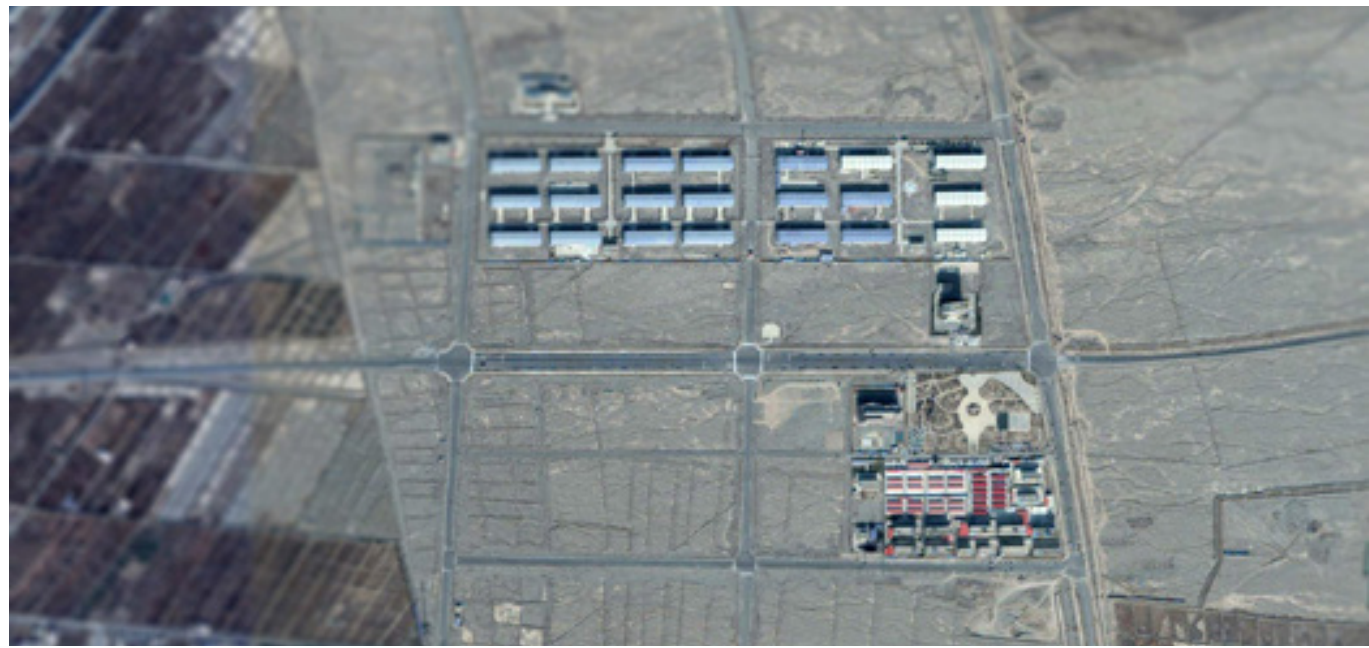

Atushi city education camps in Xinjiang PC: ABC.net.

place'. Provisions such as this one seem to be part of the basis for the vast expansion of 'Education Centres', an archipelago of detention facilities that are estimated to hold over a million people (Nebehay 2018)-a population that could exceed the total number of people in all of China's Ministry of Justice prisons. If developments in criminal procedure have constrained variation in penal severity among individuals, the bifurcated state has ramped up variation in penal severity among whole groups. The Xinjiang experience of penal severity stands as a dual state exception, but it is an exception of such scale that it may also be regarded as the penal norm.

\section{An Open-ended Question}

If the conversation is still going at this point, whoever asked whether punishment in China is harsh may be rethinking the choice of discussion topic (or at least the choice of discussion partner). I have identified a wide variety of possible comparators of penal severity-quantities (penal scale, rate of incarceration, sentence length), qualities (transparency and opacity), and variations (procedural protections and exceptions). Although each of these comparators holds some appeal, none is particularly satisfying. Taken together, even less so. They are both too many and too few. Too many, because they forestall a single comparison; too few, as even the most cursory consideration reveals these comparisons as being far from exhaustive. For Whitman the assessment that America is harsher than Europe was obvious; the puzzle to be explained was why this was the case. As for China, the question of severity, whether measured against the United States, its own past, or some other metric-remains unsettled. It is something we will keep talking about. 